\title{
Reflections on the Implementation of Competence Based Curriculum in Tanzanian Secondary Schools
}

\author{
Sotco Claudius Komba ${ }^{1} \&$ Marcus Mwandanji ${ }^{2}$ \\ ${ }^{1}$ Senior Lecturer, Department of Social Sciences, Sokoine University of Agriculture, Morogoro, Tanzania \\ ${ }^{2}$ Senior Education Officer, Mbeya City Council, Mbeya, Tanzania \\ Correspondence: Sotco Claudius Komba, Department of Social Sciences, Sokoine University of Agriculture, P.O. \\ BOX 3038 Chuo Kikuu, Morogoro, Tanzania. Tel: 255-23-260-3404. E-mail: sotratz@yahoo.com
}

Received: February 6, 2015

Accepted: February 16, 2015

Online Published: May 29, 2015

doi:10.5539/jel.v4n2p73

URL: http://dx.doi.org/10.5539/jel.v4n2p73

\begin{abstract}
This study investigated issues surrounding the implementation of competence based curriculum in Tanzanian secondary schools. The specific objectives of the study were to examine the teachers' understanding of the objectives of competence based curriculum; to investigate the teachers' abilities in preparing competence based lesson plans; to examine whether or not teachers involved students in classroom activities; and to find out whether or not teachers practiced formative students' assessments as per the requirements of competence based curriculum. The respondents included 186 teachers who were randomly selected from 13 secondary schools found in Mbeya region of Tanzania. The data were collected through interview schedules, observation schedules, and review of documents. The collected data were analysed using thematic content analysis. The findings indicated that the majority ( $86 \%$ ) of the interviewed teachers did not have the proper understanding of the objectives of competence based curriculum. In addition, the majority (78\%) of the reviewed lesson plans did not reflect the qualities of a competence based lesson plan. Moreover, the involvement of students in classroom activities by the teachers who were observed was, in overall, very low. Lastly, teachers practiced formative students' assessments in less than $50 \%$ of the observed classroom sessions. In view of these findings, it seemed that the implementation of competence based curriculum in the selected schools was ineffective. In view of these findings, it is recommended that regular training for in-service teachers should be conducted in order to enable them acquire up-to-date teaching skills as required by the changes introduced in the school curricula.
\end{abstract}

Keywords: reflections, implementation, competence based curriculum, secondary schools, Tanzania

\section{Introduction}

There are different perceptions on the meaning of curriculum. For example, while Posner (1995) claim that it is the content or objectives for which schools hold students accountable, Taylor and Alexander, as cited in Taba (1962), define curriculum as the total efforts of the school to bring about desired outcomes in school and out of school situations. Generally, the curriculum of a school can be viewed as the formal and informal contents and processes by which learners gain knowledge and understanding, develop skills, and alter attitudes, appreciations, and values under the auspices of that school (Doll, 1978). A curriculum can either be content or competent based. A content based curriculum is based on the rote memorization of factual knowledge while competence based curriculum capitalizes on competence based learning which focuses on understanding the concepts, skills and competencies which in turn calls for changes in teaching, learning and assessment approaches (Posner, 1995).

Soon after her independence in 1961, Tanzania, like many other African countries, adopted a content based curriculum. However, in 2005, Tanzania introduced a competence based curriculum which led to the development of competence based curriculum for learning and assessments in secondary education (Kafyulilo et al., 2012). The review of the curricula was prompted by economic, political, and cultural changes. According to Komba and Kira (2013), the old curriculum was ineffective as the graduates failed to demonstrate the skills and competences that fully addressed local, national and global market demands.

Although the curriculum for any education system requires regular reviews in order to make adjustments to accommodate the ever changing societal needs, it is important to ensure that there is a mechanism to follow up on the implementation of the innovations imposed in the curriculum. Kimaryo (2011) notes that the 
implementation of competence based curriculum in schools had been complex since its introduction because teachers still focused on developing content with the hope that the learners would develop the intended competences automatically.

A good number of studies have investigated different issues on competence based curriculum (Kafyulilo et al., (2012); HakiElimu, 2012; Wangeleja, 2007; Kalugula, 2000). For example, Kafyulilo et al. (2012) conducted a study on the implementation of competence based teaching approaches in Tanzania. In this study, the authors revealed that pre-service teachers needed a kind of practices with the competence based teaching approaches in order to be able to effectively implement the approaches in their teaching. Moreover, in the studies conducted by Wangeleja (2007) and Kalugula (2000), the findings indicated that the teaching of competence based curriculum required the teachers' understanding of both the content and pedagogy. In the same light, a study conducted by HakiElimu (2012) had attributed the trend of students' poor performance in the Certificate of Secondary Education Examinations (CSEE) in Tanzania with the poor conceptualization and implementation of the education curriculum. However, there are limited studies which have been conducted to investigate whether or not the implementation of competence based curriculum in Tanzanian secondary schools was effective. In addition, a good number of years have elapsed since the introduction of competence based curriculum in Tanzania and there was no clear evidence of whether or not teachers were appropriately implementing it. In this regard, it was pertinent to conduct a study on the implementation of competence based curriculum in Tanzanian secondary schools to ascertain whether or not the implementation was effective.

Specifically, this study sought to achieve the following specific objectives: to examine the teachers' understanding of the objectives of competence based curriculum; to investigate the teachers' abilities in preparing competence based lesson plans; to examine whether or not teachers involve students in classroom activities; and to find out whether or not teachers practice formative students' assessments.

\section{Theoretical Underpinnings}

Competence based curriculum is a functional approach to education as it emphasizes life skills and evaluates mastery on skills, necessary for and individual to function proficiently in a given society (Savage, 1993). Equally important, Mosha (2012) notes that a competence based curriculum seeks to develop in learners the ability to know, to learn and learn how to learn, to do things, and to learn and work with other people. Such a shift has pedagogical implications as Rutayuga (2010) notes that competence based curriculum requires a shift from assessing a set of learning content to assessing each learning outcome. Similarly, Wood (2001) insists that the move towards competence based rather than content based curriculum necessitates student centred teaching and learning. To some scholars, such as Harris, Guthrie, Hobart and Lundberg (1995), competence based curriculum is perceived as a solution to the implementation of education and training for the complex contemporary world.

The history of competence based curriculum can be traced back to the early 1970s when competence based education emerged for the first time in the United States of America (Richard \& Rogers, 2001). It was a kind of an educational movement that defined educational goals in terms of precise measurable descriptions of knowledge, skills, and behaviours students had to posses at the end of the course of study. Thereafter, the movement spread into European countries such as the United Kingdom and Germany in the 1980s (Wolf, 2001). Australia adopted the competence based curricula in the 1990s and since then, other countries worldwide have been motivated to implement the competence based curriculum in schools due to the ever changing technology and global market. In Africa, competence based curriculum was adopted for the first time in South Africa in 1998, following the acute shortage of professionals like engineers, technicians and artisans. South Africa adopted the competence based curriculum in a bid to change attitudes of all South Africans and equip them with employable skills to cope with challenging issues in the $21^{\text {st }}$ century.

In Tanzania, the education sector has undergone several reforms since 1995 when the Education and Training Policy was issued. Most of the reforms have focused on improving access, equity, quality and capacity building. With regard to curricula review, Tanzania reviewed its education curricula at different levels of education from 2004 to 2008 . The review was basically intended to make a shift from the traditional content based curriculum to competence based curriculum. In the same light, it was also an attempt to improve the quality of education by enabling learners to develop the required competences relevant in different spheres of life.

As pointed out in the introduction section of this article, a good number of studies on competence based curriculum have been conducted. For example, Ultimo (2005) conducted a study on challenges of curriculum reform in the context of decentralization in Indonesia. The study sought to reveal teachers' responses following the implementation of competence based curriculum in schools. The findings showed that the in-service primary school teachers were equipped with only one third of the training needed for effective implementation of 
competence based curriculum. As such, they were unable to implement it in the classroom and continued to use the traditional ways of teaching which are based on content. While Ultimo's study focused on the in-service teachers at primary school level, this study focused on teachers who were involved in the implementation of competence based curriculum at secondary school level. In addition, Mulaudzi (2009) conducted a study in South Africa whose main objective was to investigate how educators in South Africa perceived the Outcome Based Education (OBE) system. In this system, students are required to demonstrate the skills and course contents they have learnt. The findings revealed that the successful implementation of OBE was hampered by lack of resources and lack of professional framework of continuing professional development and support programmes. Considering that these studies were conducted outside the Tanzanian context, the need to conduct a study to investigate the implementation of competence based curriculum in the context of Tanzanian secondary schools was pertinent.

\section{Methodology}

In this study, a case study research design was adopted because it involves a thorough descriptive analysis of a single individual, group or events. The case study is especially useful when the overall objective of the study is to investigate, explore and analyze a single unit such as a person, family, institution, culture group or even an entire community to represent the nation or the entire population of a certain region (Gall et al., 1996). The current study was conducted in Mbeya, one of the regions of Tanzania. This region was randomly selected to represent other regions in Tanzania which have teachers and schools with more or less the same characteristics. The sample for this study comprised 186 teachers who were randomly selected from 13 secondary schools found in the region. The teachers were interviewed on their understanding of the concept and objectives of competence based curriculum. In addition, a total of 24 lesson plans, randomly selected from some of the interviewed teachers were reviewed in order to establish whether or not their contents reflected the qualities of a competence based lesson plan. The review of the lessons plans was done against indicators shown in Table 1. Moreover, a total of 24 classroom observations were made to examine whether or not teachers involved students in classroom activities and practiced formative students' assessments during the teaching/learning process. The observations were made against indicators developed by the researchers, as indicated in Tables 2 and 3. The data collected through interview schedules, review of documents and classroom observation were analysed using thematic content analysis.

\section{Findings and Discussion}

\subsection{Teachers' Understanding of the Concept and Objectives of Competence Based Curriculum}

The first objective of this study was to examine the teachers' understanding of the objectives of competence based curriculum. This objective was included in this study in view of the fact that the successful implementation of competence based curriculum was essentially dependent upon the teachers' readiness and understanding of the initiative. To achieve this objective, teachers were asked questions during interviews which focused on two thematic areas: the general understanding of the concept of competence based curriculum; and objectives of competence based curriculum. The findings showed that the majority $(86 \%)$ of the interviewed teachers did not have the proper understanding of the concept of competence based curriculum nor were they knowledgeable about the objectives of competence based curriculum. For instance, when the respondents were asked to explain the objectives of implementing competence based curriculum in Tanzania, one of the respondents had this to say:

I do not really know the objectives of competence based curriculum! First of all, let me tell you something..... when I was pursuing my degree programme in education, I was not taught about the so called competence based curriculum. I was neither told that upon the completion of my degree programme, I would be involved in the implementation of competence based curriculum in schools. To be honest, I do not even know what the competence based curriculum is all about!

When this excerpt is examined, it seems that a link was missing between the way the teachers were being prepared in the teacher training institutions and the actual pedagogical implementation in the schools. In essence, the objectives of competence based curriculum can be categorized into two: first, the objectives for students which focus on the present and future jobs of the learners, addressing the ever-changing market demands, satisfying both the present and future customers and satisfying the local and global demands. Secondly, the objectives of competence based curriculum focus on teachers' effectiveness in the use of interactive, participatory teaching and learning techniques and a child learning environment (Mringi, 2012). The observation that the majority of teachers did not know the objectives of competence based curriculum seemed to be a challenge considering that teachers are the cornerstone in the implementation of any educational initiative. 
These findings agree with those of HakiElimu (2012) which revealed that competence based curriculum in schools had always been poorly implemented as the majority of teachers did not understand the requirements of the new curriculum.

\subsection{Teachers' Ability to Prepare Competence Based Lesson Plans}

The second objective of this study sought to examine the teachers' ability to prepare competence based lesson plans. In order to achieve this objective, a review of sampled teachers' lesson plans was done against eight indicators. The indicators focused on whether or not the learning outcomes were stated using verbs which specified the skills/abilities that were expected to be attained/exhibited by the students after the lesson; the lesson plan provided an opportunity for the teacher to find out what students already knew about the topic prior to introducing new contents; the lesson plan showed the list of teaching aids to be used in facilitating the teaching and learning of the particular lesson; the lesson plan provided the link between the lesson plan contents and the real world situations; the lesson plan described the teaching and learning activities that reinforce students' understanding of the topic; the lesson plan provided an opportunity for continuous assessments of activities in groups or individually; the lesson plans provided an opportunity for use of multiple teaching and learning strategies; and whether or not the lesson plan provided a list of realistic learning tasks which aimed at the development of students' competences. The findings were as shown in Table 1:

Table 1. Findings on the review of lesson plans

\begin{tabular}{|c|c|c|c|c|}
\hline \multirow[t]{2}{*}{ Indicator } & \multicolumn{4}{|c|}{ Scale } \\
\hline & NS & PS & $\mathbf{S}$ & WS \\
\hline $\begin{array}{l}\text { The learning outcomes are stated using } \\
\text { verbs which specify the skills/abilities that } \\
\text { are expected to be attained/exhibited by } \\
\text { the students after the lesson. }\end{array}$ & $\begin{array}{l}3 \\
(13 \%)\end{array}$ & $\begin{array}{l}6 \\
(25 \%)\end{array}$ & $\begin{array}{l}11 \\
(46 \%)\end{array}$ & $\begin{array}{l}4 \\
(16 \%)\end{array}$ \\
\hline $\begin{array}{l}\text { The lesson plan provides an opportunity } \\
\text { for the teacher to find out what students } \\
\text { already know about the topic. }\end{array}$ & $\begin{array}{l}4 \\
(16 \%)\end{array}$ & $\begin{array}{l}11 \\
(46 \%)\end{array}$ & $\begin{array}{l}6 \\
(25 \%)\end{array}$ & $\begin{array}{l}3 \\
(13 \%)\end{array}$ \\
\hline $\begin{array}{l}\text { The list of teaching aids to be used in } \\
\text { facilitating the teaching and learning of the } \\
\text { particular lesson has been shown. }\end{array}$ & $\begin{array}{l}5 \\
(21 \%)\end{array}$ & $\begin{array}{l}10 \\
(42 \%)\end{array}$ & $\begin{array}{l}8 \\
(33 \%)\end{array}$ & $\begin{array}{l}1 \\
(4 \%)\end{array}$ \\
\hline $\begin{array}{l}\text { The lesson plan links the contents of the } \\
\text { lesson to real world situation. }\end{array}$ & $\begin{array}{l}7 \\
(29 \%)\end{array}$ & $\begin{array}{l}9 \\
(37 \%)\end{array}$ & $\begin{array}{l}6 \\
(25 \%)\end{array}$ & $\begin{array}{l}2 \\
(8 \%)\end{array}$ \\
\hline $\begin{array}{l}\text { The lesson plan describes the teaching and } \\
\text { learning activities that reinforce students' } \\
\text { understanding of the topic }\end{array}$ & $\begin{array}{l}2 \\
(8 \%)\end{array}$ & $\begin{array}{l}5 \\
(21 \%)\end{array}$ & $\begin{array}{l}12 \\
(50 \%)\end{array}$ & $\begin{array}{l}5 \\
(21 \%)\end{array}$ \\
\hline $\begin{array}{l}\text { The lesson plan provides an opportunity } \\
\text { for continuous assessment of activities in } \\
\text { groups or individually to find out whether } \\
\text { students have developed the intended } \\
\text { skills/competences. }\end{array}$ & $\begin{array}{l}10 \\
(42 \%)\end{array}$ & $\begin{array}{l}7 \\
(29 \%)\end{array}$ & $\begin{array}{l}6 \\
(25 \%)\end{array}$ & $\begin{array}{l}2 \\
(8 \%)\end{array}$ \\
\hline $\begin{array}{l}\text { The lesson plan provides an opportunity } \\
\text { for the use of multiple teaching and } \\
\text { learning strategies in order to meet needs } \\
\text { of each student }\end{array}$ & $\begin{array}{l}6 \\
(25 \%)\end{array}$ & $\begin{array}{l}9 \\
(38 \%)\end{array}$ & $\begin{array}{l}8 \\
(33 \%)\end{array}$ & $\begin{array}{l}1 \\
(4 \%)\end{array}$ \\
\hline $\begin{array}{l}\text { The lesson plan shows a design of realistic } \\
\text { learning tasks which aim at the } \\
\text { development of students' competences. }\end{array}$ & $\begin{array}{l}5 \\
(21 \%)\end{array}$ & $\begin{array}{l}9 \\
(38 \%)\end{array}$ & $\begin{array}{l}6 \\
(25 \%)\end{array}$ & $\begin{array}{l}4 \\
(16 \%)\end{array}$ \\
\hline
\end{tabular}

Note. Not Shown; PS= Partially Shown; $\mathrm{S}=$ Shown; WS= Well Shown. 
Table 1 indicates that the majority of the reviewed lesson plans did not have the qualities of a competence based lesson plan. For example, in one of the reviewed geography lesson plans for form two students, the learning outcomes were stated as follows:

\section{i. Students should be able to know contours.}

ii. Students should be able to understand the use of contours in maps.

If these two learning outcomes are carefully analysed, one could conclude that the outcomes were not stated using verbs which specified the skills/abilities that were expected to be attained/exhibited by the students after the lesson. The verbs know and understand do not indicate what exactly the students should attain after the lesson as they are just too general. It was shocking to learn that many other lesson plans had similar weaknesses. For example, while only $37 \%$ of the lesson plans indicated the list of teaching aids to be used in facilitating the teaching and learning of the particular lesson, the number of lesson plans which indicated the provision of opportunities for continuous assessments of activities in groups or individually constituted only $33 \%$. It means that more that $60 \%$ of the lesson plans did not indicate either the list of teaching aids or provision of opportunities for continuous students' assessments. This implies that the implementation of competence based curriculum in schools was to a great extent, ineffective. The findings agree with those of Kafyulilo et al. (2012) who found that although the pre-service teachers learned about competence based teaching approaches theoretically at the respective colleges, they had limited abilities to demonstrate the approaches in classroom situations.

\subsection{Involvement of Students in Classroom Activities}

The third objective of this study sought to examine whether or not teachers were involving students in classroom activities. In order to achieve this objective, a total of 24 classroom observations were made on the basis of seven indicators developed by the researchers. The indicators focused on whether or not teachers asked students pertinent questions and respected students' ideas; teachers provided collaborative tasks for students to do in the classroom; students talked to and/or with their teachers during the lessons; teachers directed questions to specific students and distributed turns around the classrooms; teachers encouraged students to ask questions during the learning process; teachers provided opportunities for students to make demonstrations; and whether or not teachers provided constructive feedback to their students during the teaching/learning process. The findings were as shown in Table 2:

Table 2. Classroom observation on the involvement of students in classroom activities

\begin{tabular}{|c|c|c|c|c|}
\hline \multirow[t]{2}{*}{ Indicator } & \multicolumn{4}{|c|}{ Scale } \\
\hline & ND & PD & D & WD \\
\hline $\begin{array}{l}\text { The teacher asks students pertinent questions and } \\
\text { respects students' ideas. }\end{array}$ & $\begin{array}{l}0 \\
(0 \%)\end{array}$ & $\begin{array}{l}5 \\
(21 \%)\end{array}$ & $\begin{array}{l}9 \\
(37 \%)\end{array}$ & $\begin{array}{l}10 \\
(42 \%)\end{array}$ \\
\hline $\begin{array}{l}\text { The teacher provides collaborative tasks for } \\
\text { students to do in the classroom }\end{array}$ & $\begin{array}{l}6 \\
25 \%\end{array}$ & $\begin{array}{l}8 \\
(33 \%)\end{array}$ & $\begin{array}{l}7 \\
(29 \%)\end{array}$ & $\begin{array}{l}3 \\
(13 \%)\end{array}$ \\
\hline Students talk with the teacher & $\begin{array}{l}6 \\
(25 \%)\end{array}$ & $\begin{array}{l}9 \\
(37 \%)\end{array}$ & $\begin{array}{l}6 \\
(25 \%)\end{array}$ & $\begin{array}{l}3 \\
(13 \%)\end{array}$ \\
\hline $\begin{array}{l}\text { The teacher directs questions to specific students } \\
\text { and distribute turns around the classroom }\end{array}$ & $\begin{array}{l}4 \\
(16 \%)\end{array}$ & $\begin{array}{l}8 \\
(34 \%)\end{array}$ & $\begin{array}{l}7 \\
(29 \%)\end{array}$ & $\begin{array}{l}5 \\
(21 \%)\end{array}$ \\
\hline $\begin{array}{l}\text { The teacher encourages student questions and } \\
\text { engagement in the learning process }\end{array}$ & $\begin{array}{l}10 \\
(42 \%)\end{array}$ & $\begin{array}{l}7 \\
(34 \%)\end{array}$ & $\begin{array}{l}5 \\
(21 \%)\end{array}$ & $\begin{array}{l}2 \\
(8 \%)\end{array}$ \\
\hline $\begin{array}{l}\text { The teacher invites students to make } \\
\text { demonstrations on the blackboard. }\end{array}$ & $\begin{array}{l}12 \\
(49 \%)\end{array}$ & $\begin{array}{l}4 \\
(17 \%)\end{array}$ & $\begin{array}{l}4 \\
(17 \%)\end{array}$ & $\begin{array}{l}4 \\
(17 \%)\end{array}$ \\
\hline $\begin{array}{l}\text { The teacher provides constructive feedback to } \\
\text { students in the learning process. }\end{array}$ & $\begin{array}{l}5 \\
(21 \%)\end{array}$ & $\begin{array}{l}9 \\
(38 \%)\end{array}$ & $\begin{array}{l}8 \\
(33 \%)\end{array}$ & $\begin{array}{l}2 \\
(8 \%)\end{array}$ \\
\hline
\end{tabular}

Note. $\mathrm{ND}=$ Not Done; $\mathrm{PD}=$ Partially Done; $\mathrm{D}=$ Done; $\mathrm{WD}=$ Well Done. 
As shown in Table 2, it seemed that the involvement of students in classroom activities was very low in all of the observed classroom sessions. For example, in one of the sessions, the teacher taught for 80 minutes but it was surprising that the communication was only unidirectional (teacher-students) such that students had no opportunities to interact with the teacher or among themselves. In the same session, it was also revealed that there were no collaborative tasks provided by the teacher for students to do in the classroom.

In a competence based curriculum it is required that students be provided with experiences (in and outside the classroom) that give them opportunities to apply their skills and knowledge to solve challenging problems. This is accomplished through involving students in classroom activities which enable them to gain hands-on experiences that have a far reaching impact as far as the students' comprehension of the taught content is concerned (Wangeleja, 2010).

The observation that the involvement of students during the lessons was low implies that teachers were not examining whether students were academically progressing well or not. This concurs with Marks' (2000) observation that although student engagement with the intellectual work of school is important to students' achievement and to their social and cognitive development, studies have documented low levels of engagement, particularly in classroom situations. In addition, Gabriel (2010) found that teachers were unable to use highly and potentially interactive teaching methods such as problem-solving and discovery. However, the findings of this study are dissimilar from those of Fakery (2010) who found that teachers played significant roles towards enhancing students' participation in classroom activities.

\subsection{Teachers' Practice of Formative Students' Assessments}

The fourth objective of this study was to investigate whether or not teachers practiced formative students' assessments during the teaching/learning process. In order to achieve this objective, a total of 24 classroom observations were made using six indicators as developed by the researchers. The indicators focused on whether or not teachers provided appropriate and regular performance tasks during the teaching/learning process; teachers guided the students through the process of teaching/learning to self-assess and understand both peer and teacher feedback; teachers provided opportunities for students to express their understanding and classroom dialogue that focused on exploring understanding of concepts and ideas; teachers provided verbal or written feedback which was detailed and guided students to make further progress and improvements; students were given opportunities to interact among themselves in a bid to develop and demonstrate their understanding of concepts; and whether or not students were given opportunities to organize information, make connections, and note relationships among the learned ideas. The findings were as shown in Table 3:

Table 3. Classroom observation on formative students' assessment

\begin{tabular}{|c|c|c|c|c|}
\hline \multirow[t]{2}{*}{ Indicator } & \multicolumn{4}{|c|}{ Scale } \\
\hline & ND & PD & D & WD \\
\hline $\begin{array}{l}\text { The teacher provides appropriate and regular quizzes, home } \\
\text { works, or performance tasks in the learning process }\end{array}$ & $\begin{array}{l}3 \\
(13 \%)\end{array}$ & $\begin{array}{l}12 \\
(50 \%)\end{array}$ & $\begin{array}{l}5 \\
(21 \%)\end{array}$ & $\begin{array}{l}4 \\
(16 \%)\end{array}$ \\
\hline $\begin{array}{l}\text { The teacher guides students through the process of learning to } \\
\text { self-assess and understand both peer and teacher feedback }\end{array}$ & $\begin{array}{l}5 \\
(21 \%)\end{array}$ & $\begin{array}{l}8 \\
(33 \%)\end{array}$ & $\begin{array}{l}6 \\
(25 \%)\end{array}$ & $\begin{array}{l}5 \\
(21 \%)\end{array}$ \\
\hline $\begin{array}{l}\text { The teacher provides opportunities for students to express their } \\
\text { understanding and classroom dialogue that focuses on } \\
\text { exploring understanding. }\end{array}$ & $\begin{array}{l}2 \\
(8 \%)\end{array}$ & $\begin{array}{l}10 \\
(42 \%)\end{array}$ & $\begin{array}{l}6 \\
(25 \%)\end{array}$ & $\begin{array}{l}6 \\
(25 \%)\end{array}$ \\
\hline $\begin{array}{l}\text { The teacher provides verbal or written positive feedback which } \\
\text { is detailed and guides students to make further progress. }\end{array}$ & $\begin{array}{l}4 \\
(17 \%)\end{array}$ & $\begin{array}{l}10 \\
(41 \%)\end{array}$ & $\begin{array}{l}6 \\
(25 \%)\end{array}$ & $\begin{array}{l}4 \\
(17 \%)\end{array}$ \\
\hline $\begin{array}{l}\text { Students are given the opprtunity to move and/or communicate } \\
\text { with others as they develop and demonstrate their } \\
\text { understanding of concepts. }\end{array}$ & $\begin{array}{l}11 \\
(46 \%)\end{array}$ & $\begin{array}{l}6 \\
(25 \%)\end{array}$ & $\begin{array}{l}5 \\
(21 \%)\end{array}$ & $\begin{array}{l}2 \\
(8 \%)\end{array}$ \\
\hline $\begin{array}{l}\text { Students are given the opportunity to organize information, } \\
\text { make connections, and note relationships among the learned } \\
\text { ideas }\end{array}$ & $\begin{array}{l}5 \\
(21 \%)\end{array}$ & $\begin{array}{l}12 \\
(50 \%)\end{array}$ & $\begin{array}{l}5 \\
(21 \%)\end{array}$ & $\begin{array}{l}2 \\
(8 \%)\end{array}$ \\
\hline
\end{tabular}

Note. $\mathrm{ND}=$ Not Done; $\mathrm{PD}=$ Partially Done; $\mathrm{D}=$ Done; $\mathrm{WD}=$ Well Done. 
As shown in Table 3, teachers did not seem to practice formative students' assessments in most of the observed classroom sessions. This seemed to be a challenge, considering that the information from formative assessments of students is essentially pertinent when there is a need to adapt teaching and learning to meet students' needs. When teachers know how students are progressing and where they are having trouble, they can use information from formative assessment to make necessary instructional adjustments, such as re-teaching, trying alternative instructional approaches, or offering more opportunities for practice (Black \& William, 1998).

\section{Conclusion and Recommendations}

Although from 2005, Tanzania started to implement the competence based curriculum in secondary schools, the findings of this study have revealed that the majority of teachers were not knowledgeable on what competence based curriculum was all about. In addition, the practices exhibited by the majority of teachers in the selected schools did not indicate that they were effectively implementing competence based curriculum. Since teachers are the cornerstone in the implementation of any educational innovation, the implementation of competence based curriculum in Tanzanian schools is essentially dependent upon the teachers' knowledge and skills on what the competence based curriculum entailed. In this regard, the following recommendations are made: first, the Ministry of Education and Vocational Training should improve the teacher training programmes in order to provide pre-service teachers with necessary skills for the implementation of competence based curriculum in schools. Secondly, since curricula changes and introduction of new approaches for teaching and learning are inevitable, the responsible authorities should conduct regular training for in-service teachers to enable them acquire up-to-date teaching skills as required by the changes introduced in the school curricula.

\section{References}

Black, P., \& Wiliam, D. (1998). Inside the black box: Raising standards through classroom assessments. Phi Delta Kappan, 80(2), 139-148.

Doll, R. C. (1978). Curriculum improvement: Decision making and process. Boston: Allyn and Bacon.

Fakeye, D. O. (2010). Students' personal variables as correlates of academic achievement in English as a second language in Nigeria. Journal of Social Sciences, 22(3), 205-211.

Gall, D. M., Borg, W. R., \& Gall, J. P. (1996). Educational research: An introduction. New York: Longman Publishers.

HakiElimu. (2012). School children and national examinations: A research report on the relationship between examination practice and curriculum objectives. Dar es Salaam: Hakielimu.

Harris, R., Guthrie, H., Hobart, B., \& Lundberg, D. (1995). Competence-based education and training: Between a rock and a whirlpool. South Melbourne: Macmillan Education.

Kafyulilo, A. C., Rugambuka, B. I., \& Moses, I. (2012). The implementation of competence based teaching approaches in Tanzania. Makerere Journal of Higher Education, 4(2), 311-326.

Kalugula, C. (2001). Have teachers stopped teaching? In G. Hoejlund, N. Mtana, \& E. Mhando (Eds.), Practice and Possibility in Teacher Education in Africa: Perspective from Tanzania (pp. 321-329). Dar es Salaam: Ministry of Education.

Kimaryo, L. A. (2011). Integrating environmental education in primary school education in Tanzania: Teachers' perceptions and teaching practices. Finland: Abo Akademi University Press.

Komba, S. C., \& Kira, E. S. (2013). The effectiveness of teaching practice in improving student teachers' teaching skills in Tanzania. Journal of Education and Practice, 4(1), 157-163.

Komba, S. C., Kafanabo, E. J., Njabili, A. F., \& Kira, E. S. (2012). Comparison between students' academic performance and their abilities in written English language skills: A Tanzanian perspective. International Journal of Development and Sustainability, 1(2), 305-325.

Komba, S. C., \& Kafanabo, E. J. (2012). Investigation of the predictive validity of communication skills examination on university students' overall academic performance in Tanzania. International Journal of Education, 4(4), 248-266. http://dx.doi.org/10.5296/ije.v4i4.2557

Marks, H. M. (2000). Student engagement in instructional activity: Patterns in the elementary, middle, and high school years. American Educational Research Journal, 37(1), 153-184. http://dx.doi.org/10.3102/00028312037001153

Mlaudzi, N. (2009). Implementation of the South African national curriculum. 
The educators' perspectives. (2009). Issues and challenges in education in Africa-the need for a "new" teacher. Limpopo, South Africa.

Mosha, H. J. (2012). Common core skills for lifelong learning and sustainable development in Africa: A case study of learning materials used to deliver knowledge and skills-or competency-based curricula in Tanzania. A paper presented at the Triennale on education and training in Africa (Ouagadougou, Burkina Faso, February, 12-17, 2012).

Posner, G. J. (1995). Theoretical perspectives on curriculum. MA: Pearson Custom Publishing.

Richards J., \& Rodgers, T. (2001). Approaches and methods in language teaching. New York: Cambridge University Press. http://dx.doi.org/10.1017/CBO9780511667305

Rutayuga, B. A., \& Kondo, A. (2006). A shift from a set of learning contents to assessing each learning outcome. Dar es Salaam: NACTE.

Savage, L. (1993). Literacy through a competency-based education approach. Washington DC: Center for Applied Linguistics.

Taba, H. (1962). Curriculum development: Theory and practice. Harcourt, Brace and World, Chicago.

Tyler, R. W. (1949). Basic principles of curriculum and instruction. University of Chicago Press.

Utomo, E. (2005). Challenges of curriculum reform in the context of decentralization: The response of teachers to a competence based curriculum at its implementation in schools. Indonesia: University of Pittsburgh.

Wangeleja, M. J. N. (2010). The teaching and learning of competence based mathematics curriculum: Methods and techniques. A paper presented at the annual seminar of the mathematical association of Tanzania at Solomon Mahlangu Campus of Sokoine University of Agriculture, Morogoro13-18/9/2010.

Wolf, A. (2001). Competence based assessments. The British Journal of General Practice, 55(515), 461-467.

World Bank. (2011). A regional exploration of pathways toward harmonization of mathematics and science curriculum in the East African Community. Discussion Paper. Washington D.C: World Bank.

\section{Copyrights}

Copyright for this article is retained by the author(s), with first publication rights granted to the journal.

This is an open-access article distributed under the terms and conditions of the Creative Commons Attribution license (http://creativecommons.org/licenses/by/3.0/). 